\title{
THE WAYS TO ESTABLISH THE PERSONALITY ORIENTED PARADIGM IN THE UKRAINIAN SCHOOL EDUCATION (PSYCHO-PEDAGOGICAL ASPECT)
}

\author{
Natalia Dichek \\ Doctor of Sciences in Pedagogy, Professor \\ Head of Laboratory of History of Education \\ The Institute of Pedagogy \\ National Academy of Pedagogical Sciences of Ukraine, Ukraine \\ ip.istp@gmail.com \\ $+380444813881$ \\ ORCID ID 0000-0002-2185-3630
}

\section{ABSTRACT}

In the context of representing the ideas of individualization of school education developed in Ukraine in the last third of the XX century and their implementation in the educational process, the poorly studied issue, namely, the Ukrainian psychologists' contribution to the research of the ways and the means of teaching individualization that was conducted in the late 1980s - the first half of the 1990s was covered. The major areas of research in educational psychology, personality psychology that dealt with deepening learning individualization, that is, developing a system of differentiation of primary and secondary schools, the implementation of the applied psychology achievements, in particularly, the organization of psychological services in the school system, the study of the pupils' creative potential, discovering and development of their talent as well as creative thinking were outlined. The analysis of the psychological and educational outcomes of the Ukrainian scholars proved the focus of the research on humanization of the educational process, the ways to ensure meeting the pupils' individualized needs in the learning process that corresponded to the establishment of a personality oriented paradigm in the Ukrainian education.

Keywords: classes of the increased individual attention; classes of the accelerated development; classes of the age norms; individualization of the learning process; practical psychology; psychological services; personal approach.

\section{INTRODUCTION}

In a chronological and problematic dimension, this article is a logical extension of the researches that have already been conducted by us and covered the representation and the analysis of the achievements of Ukrainian scientists and psychologists who formed the gradual spread of the differentiation processes for the high school students (Dichek N. P., 2013). It is noteworthy to emphasize that these important aspects of national school educational process remain to be unrepresented up to this day.

The purpose of the article is to find out the main directions of the research in the differentiation and individualization of school teaching and the changes in the scientific vectors in this area due to a change of government in Ukraine by means of the analysis on the Ukrainian psychologists' achievements in the late 1980s - early 1990s. For this purpose, we limit the sphere of our scientific search 
by the display of only those studies that were provided in the objective field of the educational psychology.

\section{METHODOLOGY}

In the previous studies, we have found out that since mid-1980s, the methodological, theoretical and applied problems of the formation of a "comprehensively and harmoniously developed personality", which corresponded to the governing "historic decision of the party congresses" in the education area have become a priority in the Ukrainian psychologists' researches (Dichek N. P., 2015). Along withthe abovementioned issues, in the subject matter and the content of the psychological and pedagogical studies, the emphasis was put not on forming a common, impersonal-ideal "harmonious personality", but on the fulfillment of the personality oriented tasks on the children's creative development in the learning process (V. Molyako), overcoming of formalism in the purposes and approaches to the complex processes of upbringing an individual (H. Ball), the implementation of a personality-role approach (V. Voytko). We interpret the latter as a prototype of the personality oriented approach to designing the educational process at school.

\section{MAIN DIRECTIONS OF THE RESEARCH IN THE DIFFERENTIATION AND INDIVIDUALIZATION OF SCHOOL TEACHING IN THE LATE 1980S - EARLY 1990 S}

We consider the psychological and pedagogical research on interpersonal relationships of pupils conducted by the Ukrainian scholars in 1970-1980s (O. Kyrychuk, V. Kuzmenkov, M. Popov, E. Vasylevska) that included meeting the pupils' individualized needs and learning motivation (H. Ball, M. Boryshevskyi, L. Sapozhnikova, L. Taranov), ensuring learning individualization by technical creativity, discovering giftedness, and development of creative thinking (Yu. Hilbuh, V. Molyako) as the first important steps of standardization of the ideas of the personality-oriented training. Therefore, we have a reason to believe that the psychologists of Ukraine were developing a foundation for the further guidance of teaching of pupils to differentiation and individualization, and, therefore, they have contributed to the humanization of secondary education since 1990-ies.

Since the start of the development of independent Ukrainian state, in terms of the objective socio-economic difficulties, society in general and the teaching process in the secondary and higher education, in particular, faced a critical situation; O. Kyrychuk, the academician, finds that it was caused by the "deformation of the social values, ... the loss of connection with the people's spiritual roots" (Kyrychuk O. V., 1993: p. 3). Developing a concept of "a socio-cultural norm" as a regulator of a personality's activity which was new at the time for the national psychology, H. Ball, a famous Ukrainian scholar, wrote (1994) that "inappropriate pedagogical orientation are derived from the state of social consciousness" (Ball H. A., 1994: p. 79). In this way, he referred to the current situation of the Soviet pedagogy when "the moral ideals were interpreted as a compulsory requirement that led to the discredit of the ideals and the educational failure." He considered that promoting the idea of "mass heroism" as opposed to the idea of the hero as an ideal was formed under the totalitarian system and made it possible to exploit 
the enthusiasm of people, romantic impulses of the youth and to minimize the real possibility of a free personal choice in this way (Ball H. A., 1994: p. 78-79). The scholar stated that the consequence of ideological distortions was the spiritual disillusionment that was peculiar for the first years of independence.

It is noteworthy to state that in 1989, it was H. Ball who was the first Ukrainian psychologist (in collaboration with L. Taranov) to write about the personalityoriented approach as a way of defining the goals of education and training, as a concept, strategic direction for the necessary development of the educational sector on the pages of Psychology, the republican scientific-methodological collection of academic works. The authors admitted that the personality-oriented approach was "stimulating free balanced development of the individual" on the basis of combining "the principles of humanism, free development, on the one hand, and teamwork, work for the common goodness, on the other one" (Ball H. A., 1989: p. 8). Although the basis for their thoughts was the Marxism-Leninism principles, we consider the humanistic focus of their arguments to be obvious. The scholars put a strong emphasis on the importance of avoiding formalism that is harmful for education in order to ensure not only proclaiming the personality oriented educational ideas but also providing their real implementation in the efforts aimed at the achievement of the socially significant goals. Revealing the aims of education as the purposes of upbringing an individual, the authors determined two aspects in "every integral personality that really has to be represented in the activity: motivational and instrumental ones" (Ball H. A., 1989: p. 10); therefore, in the latter, they considered content and operational components (based on the concept of H. Kostyuk, a prominent Ukrainian psychologist).

In the early 1990s, the full release of the Ukrainian humanitarian thought from the tough obstacles of mono-ideology facilitated the spread of ideas about the need to humanize the whole education sector. One of the ways for it was the intensive use of practical psychology. Outlining the state and the prospects of practical psychology in the system of education in Ukraine in 1993, O. Kyrychuk, an academician, wrote that the humanistic approach was becoming increasingly recognizing in the system of the Ukrainian public education; it was featured by "paying attention at the emotional aspects of interaction between a teacher and pupils, and, correspondingly, the transfer of the focus from the teaching process to the process of cognition, from the process of upbringing to the process of selfupbringing" (Kyrychuk O. V., 1993: p. 3).

In the context of the abovementioned approach, the focus of the psychologists and educators shifted from the students' cognitive development, understanding of the teaching material by them (which were dominating during the 19501970s) to the issues of pedagogical interaction of a teacher and a pupil, which was regarded as a transfer (exchange) of the theoretical and the practical knowledge and the transfer (exchange) of the spiritual values (Kyrychuk O. V., 1991: p. 11). Recognition of upbringing a socially active, humanistically aimed personality, who is guided by the universal cultural and national values as a teacher's main purpose (Kyrychuk O. V., 1993: p. 5) encouraged the scholars to justify the need for the social and psychological tools of influence on upbringing an individual. In accordance with O. Kyrychuk, the education community had to move away from the established, traditional views on the main "subjects of the educational process." Based on the sociological research, he specified functioning of five external factors of impact that determined upbringing a personality and formed a certain 
integrity at each stage of its ontogeny (family, school, media and communications, the contact group (class, group, associations), informal group (reference one) (Kyrychuk O. V., 1993).

As it has been demonstrated in our previous studies, due to the appeal of the Ukrainian psychologists to the problem of humanization in education at the end of 1980 and the provision of the personality-oriented content in the first years of independence, they were involved in the development of the problems of studying the impact of the system of the abovementioned factors, in general, and each of them, in particularly, on the development of a growing up personality that intensified the development of such scientific and practical area as practical psychology that was associated with the differentiation and the individualization of the Ukrainian school area. It was stated that one of the principles of the educational process at school is recognized as its "differentiation and individualization with the inevitable consideration of the current level of the pupils' physical and spiritual development” (Kyrychuk O. V., 1993: p. 7).

It is significant to emphasize that Ukrainian governmental bodies have supported such researches. In the beginning of 1990s, a series of documents that defined the organizational principles of a state system of practical psychology and its corresponding funding has been developed. In October 1990, the decision No. 05-17 / 11-43 of the Commission of Public Education and Science of the Verkhovna Rada of Ukraine (Kyrychuk O. V., 1993: p. 7) launched the development of practical psychology officially. Moreover, in February 1991, an Order of P. Talanchuk, the Minister of Education of Ukraine, "On the development of practical psychology in education" appeared; it introduced psychological service officially (Kyrychuk O. V., 1993: p. 7). Accordingly, on the basis of the Institute of Psychological Research of the Academy of Educational Sciences of Ukraine, a Scientific and Methodological Department of Practical Psychology was founded.

For the subject of our research, it is extremely important to remember that the abovementioned Department consisted of the following subsections: 1) Center for Psychological Services in the Educational System of Ukraine; 2) Center for Creative Giftedness and Stimulating Creative Activity of Children; 3) Center for Providing Help for Children with Disabilities in the Psychophysiological Development and Behavior; 4) Center for Psychological and Educational Assistance "Children of Chernobyl"; 5) Center for Diagnostics and Correction of Physiological Conditions; 6) "Psychogenesis" Center of Training, Retraining and Advanced Training in Practical Psychology (Kyrychuk O. V., 1993: p. 7-8). This list clearly states that the work of the Centre laid a basis for a new step in the implementation of the ideas of individualization and differentiation especially in the field of school education, as the main task of psychological services was recognized to be "the improvement of the educational process in educational establishments", by providing them "conditions for the self-education and the self-development of each pupil" (Kyrychuk O. V., 1993: p. 7), the widest possible implementation of psychological knowledge in school practice. It was to be encouraged by the foundation of the laboratories of practical psychology in five Ukrainian universities (Kyiv, Poltava, Nizhyn, Kirovograd, Uman).

However, as it was argued by V. Panok, the psychologist, in 1992, the reason for the growth of the demand for practical psychology became "radical changes in the structure and methods of governance, implementation of humanistic principles in 
the relations between the state and the individual" (Panok V. H., 1993: p. 14) as the crash of administrative management prompted government agencies to search for the more effective management of social processes. The scholar also admitted that awareness of the need for psychological knowledge in the educational process started "from the low areas", an increasing number of schools that took advantage from their financial independence included a school psychologist to the staff, and more than a third of the delegates of the Congress of Educationists of Ukraine underscored the need for a psychological service in education (1992) (Panok V. H., 1993: p. 16). Learning differentiation, improving education quality, development of abilities and talents of children were recognized as the key tasks of school education, and the scientist emphasized that without psychologists and psychology, career counseling and problem solving in professional selection, complex upbringing, creation of a new textbook, forecasting the features of mental development of children were impossible (Panok V. H., 1993: p. 17).

It is noteworthy to state that in 1993, in the State national program "Education" (Ukraine XXI century), one of the first important national documents in the area of education of sovereign Ukraine, which was aimed to outline strategic objectives, priority areas and basic ways of reform in terms of state independence (State national program "Education": Ukraine XXI century, 1993), the need to found "comprehensive educational establishments for the psychological, social and educational services" was proclaimed. They were regarded as one of the main ways to reform secondary education. We would like to add that the abovementioned program was the first ideological reference point, a certain conceptual provision for the work on the further upgrade and development of the national education system.

The analysis of the processes associated with the problem of differentiating teaching high school students in the considered period of time shows a significant increase in the attention paid by the government to the problems of gifted children, children with psychophysiological disabilities, children who have experienced life challenges as a result of the Chernobyl disaster (we find it can be explained by the activity of scientific and educational communities and their influence on making crucial decisions).

In October 1991, a comprehensive program for the search, training and education of the gifted children and the youth, developed by the joint efforts of the staff of research institutes of Ukraine, Ministry of Education of Ukraine, Ministry of Higher Education of Ukraine, Ministry of Youth and Sports, Ministry of Health of Ukraine was approved (Kyrychuk O. V., 1993: p. 9). Due to these lay-outs, in the abovementioned State National Program "Education" (State national program "Education": Ukraine XXI century, 1993), the "creation of a system of search, development, and support of young talents and gifts to form the artistic and the scientific elite in different areas of public life; stimulation of creative self-development of children and youth" were mentioned among the strategic objectives and directions of reforming the out-of-school training and education (State national program "Education": Ukraine XXI century, 1993).

Highlighting the areas of the activity of the center to help children with psychophysiological disabilities and behavior, O. Kyrychuk, the academician, acknowledged that in that period of time, the Ukrainian psychologists were not studying children with severe speech disorders, combined disabilities, cerebral palsy, profound mental retardation whereas their amount was 
increasing” (Kyrychuk O. V., 1993: p. 9; p. 14). The scientist said that in Ukraine five existing types of special schools for children with developmental disabilities were not provided enough help in the psychological aspect, and therefore, it was necessary to expand the study of these problems. As he found out, the achievements of the center included the foundation of the psychodiagnostic complex for the regional psychological, medical and educational commissions and the publication of the manual "Psychodiagnostics of Abnormalities in the Children's Development”, designed to help school psychologists in the study of children who have difficulties in learning (Kyrychuk O. V., 1993: p. 9).

We find that one of the examples of the crucial changes of psychological thought in Ukraine is returning to the scientific and practical turn of psycho-diagnostics as an effective tool of studying the nature of a child. The following data was discovered: as early as in 1975 in the Research Institute of Psychology of the USSR (currently, it is H. S. Kosyuk Institute of Psychology of the NAES of Ukraine) founded the Laboratory of Psychodiagnostics, which was chaired by Yu. Hilbuh, a well-known psychologist, one of the founders of modern psychological diagnostics in Ukraine (H. S. Kostyuk Institute of Psychology [Electronic resource]). In the scientific department, methodological, theoretical and practical problems associated with the creation of new tests, adapting the known traditional methods, diagnosis of different populations of children and adults, as well as the introduction of psycho-diagnostics in the school practice were under consideration. However, in the early 1980s, Laboratory operation ceased to exist (L. Kondratenko). In 1989, its work was restored by the foundation of the Laboratory of Psychodiagnosis and Psychology of Differentiated Learning, which was aimed at "removing from distortions, on the one hand, and stereotyped, one-sided negative approach to it, on the other hand, from the ideas of differentiation of pupils in certain types of classes" (Hilbukh Yu. Z., 1991: p. 63). The head of the Laboratory of Psychodiagnosis became Yu. Hilbuh again. These were the laboratory scientists who proved the need for introducing the positions of school psychologists in Ukraine, as it was reflected in the State national program "Education" (State national program "Education": Ukraine XXI century, 1993).” Particular attention of the Laboratory staff was paid at creating special training programs and facilities, which could be followed by the teachers and school psychologists to ensure work with different categories of children. The Laboratory of psychodiagnosis initiated and conducted a large-scale experiment on the differentiated teaching of children, which covered hundreds of schools in Ukraine, Russia, Belarus and Moldova (H. S. Kostyuk Institute of Psychology [Electronic resource]).

Yu. Hilbukh became the first Ukrainian psychologist who developed and approbated the introduction of the so-called class alignment, and then, a system of three types of classes in the primary school along with colleagues. The latter provided for the differentiated division of the first classes on the basis of a series of portable test methods that have been developed in the Laboratory of Differentiated Learning (Hilbukh Yu. Z., 1988).

The first type of class was designed for children whose mental development corresponded to the age norm.

The second type was an accelerated learning class, intended for children with the advancing rate of mental development (training by the formula "four years in three" for the six-year olds and the students' "three years for two" for the seven-year 
olds). Training was provided in "compact programs" (Hilbukh Yu. Z., 1988: p. 97); moreover, in order to ensure their future mental development, various forms of creative and independent work, contests, distribution, cooperative problem were widely used (Hilbukh Yu. Z., 1991: p. 67). After the graduation from the primary school, such class became a class-depth study, which, in its turn, was further differentiated by means of extracurricular activities. The scientist called for the creation of a complex of the educational-subject cycles: physics and mathematics, chemistry and biology, science and humanities (linguistics, literature, art, history), polytechnic (electronics, computers, technical modeling), etc. In his conceptual approach, such cycles would be some additions to the existing curriculum and programs.

The third type was the class of high individual attention (leveling classes) for the children who were poorly prepared for school or had minor deviations in mental development. They were assigned to be trained by the qualified teachers, and the class sizes were smaller (16-18 students). In these classes, correction methods, which were developed in the Laboratory of Psychodiagnostics were applied (Yu. Hilbukh, L. Kondratenko) (Hilbukh Yu. Z., 1995: p. 97). The basis for the concept of differentiated learning developed by Yu. Hilbukh was the statement that the decisive role in learning and mental development of children is played by the time factor (Hilbukh Yu. Z., 1991: p. 63).

In early 1990s, Yu. Hilbukh recognized the differentiated learning as a basic prerequisite for implementing a key principle of pedagogy, namely, the principle of individual approach to students, that takes into account their individual psychological characteristics in the educational process (Hilbukh Yu. Z., 1991: p. 62), and he proved the feasibility not only to cover the pupils of the secondary and the high school, as it was practiced, but also primary one, where differentiated instruction was mainly implemented in the forms of extracurricular activities that covered amateur art, labor studies, physical education, "in-class differentiation" (Hilbukh Yu. Z., 1991: p. 62). Therefore, he stressed that "differentiated learning is tried to be based on the consideration of the interests and the aptitudes of pupils only, ignoring the differences in the development of intellectual abilities of individuals" (Hilbukh Yu. Z., 1991: p. 62). The scientist advocated the differentiation of pupils according to their abilities on the principle of democracy by the actual provision of all categories of children with "basically the same knowledge at a high level of assimilation." Noting the level of social stratification that was growing at that period of time, H. Ball, a professor, wrote that the classes of increased individual attention by Yu. Hilbukh really ensured the individual approach to each child, promoted individualization, which he defined as the "principal characteristic strategies for the free development of a personality" (Psychological aspects of humanizing education, 1996: p. 10-11).

At the same time, the issues of intelligence psychodiagnostics in the system of differentiation were covered by A. Furman, another Ukrainian psychologist (Furman A. V., 1993). He specified the technology of using the tests of pupils' mental development that were the most available for teachers. Along with describing the test tool of the integrated survey of pupils, the scientists set out the possibility of the tests to create different types of classes (grammar school, gymnasium, comprehensive schools, classes of the increased individual attention) and differentiated study groups for teaching gifted and slowly educated pupils.

In the early 1990s, in the Ukrainian scholars' studies, the proper attention was paid at the issue of gifted children and youth. The researchers developed the 
methods for determining the scientific and technical skills of the high school students (V. Rybalko, (Furman A. V., 1993)), training in psycho-creative work with gifted children (R. Ponomarova, A. Tereshkova, (Ponomarova R. O., Tereshkova A. D., 1993), studied the psychological basis of creativity in the area of the study of creative potential (V. Molyako (Moliako V. O., 1995), N. Chepelyeva). Since, the development of the concept of a creative human made it possible for $\mathrm{V}$. Molyako to develop a comprehensive program of educating creatively gifted children and youth; many statements were included in the referred State national program "Education" (State national program "Education": Ukraine XXI century, 1993)" (Molyako V. O., 1995: p. 148-149).

\section{CONCLUSIONS}

Completing the study of the Ukrainian psychologists' achievements in the considered time, we note that we identified only some key areas of research in school differentiation and individualization in the article. However, we got a reason to conclude that the first years of independence gave a significant impetus to expand the sphere of psychological and educational research, especially in the area of applied psychology that contributed to differentiation and individualization of the educational process in schools, the development of new technologies of the educational process in order to optimize physical, mental, social and spiritual development of pupils, and therefore, the implementation of the personality oriented paradigm of education. At the same time, we have a reason to believe that the foundations of these advanced processes were being developed in the previous decade; it is proved by the fact that at the turn of 1980-1990s, the social, the political and the ideological changes in Ukraine just laid the foundations for the changing educational paradigms when personally oriented educational paradigm replaced school paradigm.

\section{REFERENCES}

1. Ball, H., Taranov, L. (1989). The personal approach to education setting goals and ways to achieve them. Psykholohiya (Psychology): Republican scientific and methodological collection. Kyiv: Rad. Shkola (Soviet School), 32, 7-15.

2. Ball, H. (1994). Flattening of the regulatory systems of regulation of activity as a phenomenon of the totalitarian and posttotalitarian consciousness. Personality and people: the view of historical psychology: materials of all-Ukrainian scientific conference. Kyiv: Ukraine's psychologists association.

3. Bratko, M. (1993). Life purport values in primary and secondary school age. Psykholohiya (Psychology): Scientific and methodological collection. Kyiv: Osvita (Education), 41, 10-21.

4. Hilbukh, Y. (1988). Definition of psychological readiness of the child to school. Pochatkova shkola (Primary school), 7, 62-70.

5. Hilbukh, Y. Psychological preconditions of differentiated learning in primary school. Psykholohiya (Psychology): Republican scientific and methodological collection. Kyiv: Osvita, 36, 62-71.

6. Hilbukh, Y. (1995). On the ways of differentiated learning. Psychological problems of upbringing, learning, activity and development of a personality: 
materials of the summary session of the Institute of Psychology of the NAPS of Ukraine. Kyiv, 10-11, 96-102.

7. State national program "Education": Ukraine of XXI century. Osvita (Education). (1993), 44-46, 1-13.

8. Dichek, N. (2013). The contribution of our experimental pedagogy as justification for differentiation and individualization of the educational process (late XIX-1917). Differentiated approach in the history of the Ukrainian school (late XIX the first quarter of $X X$ century): multi-authored monograph. Kyiv: Ped. Dumka (Pedagogical Thought).

9. Dichek, N. (2013). Psycho-pedagogical researches in the USSR in the context of individualization of school education (1945 - the beginning of 1950th). Kyiv: Ridna shkola, 11, 29-37.

10. Dichek, N. (2013). Ukrainian psychologists' contribution to the development of individualization of teaching pupils (the second half of the 50's of the XXth century). Kyiv: Ridna shkola, 11, 35-41.

11. Dichek, N. (2014). The sources of the study of psychological and pedagogical support to the process of differentiation in high school (the late 1950's). Historical and pedagogical almanac, 2, 78-88.

12. Dichek, N. (2015). Ukrainian psychologists' contribution to the development of individualization and differentiation of educating pupils (the 60's of the XX century). Pedagogical education: theory and practice: collection of scientific works, 18 (1), 407-419.

13. Dichek, N. (2014). Research of Ukrainian psychologists in the field of school individualization of the educational process (60-70's of the XX century). Pedagogy and Psychology, 4, 76-83.

14. Dichek, N. (2015). Formation of personality oriented paradigm of school education in Ukrainian psychologists' studies (the 1980's). Pedagogy and Psychology, 4, 15-29.

15. H. S. Kostyuk Institute of Psychology. Retrieved from inpsy.naps.gov.ua/ info/185.

16. Kyrychuk, O. (1993). State and prospects of development of applied psychology in the system of education in Ukraine. Psychology: scientific and methodological collection. Kyiv: Osvita (Education), 40, 3-15.

17. Kyrychuk, O. (1991). Problems of teacher interaction. Psykholohiya (Psychology): Republican scientific and methodological collection. Kyiv: Osvita (Education), 37, 3-12.

18. Molyako, V. (1995). Psychological foundations of creativity and innovation activity of children and youth. Psychological problems of upbringing, learning, activity and development of a personality: materials of the summary scientific session of the Institute of Psychology of the NAPS of Ukraine, 10-11, 147-155.

19. Panok, V. (1993). The situation and prospects of practical psychology in Ukraine. Psychological problems of upbringing, learning, activity and development of a personality: materials of the summary scientific session of the Institute of Psychology of the NAPS of Ukraine, 22-24, 14-21.

20. Ponomarova, R., Tereshkova, A. (1993). Training on creative psychotechnics in working with gifted children and youth Psychology: Scientific and methodological collection. Kyiv: Osvita (Education), 40, 15-26. 
21. Ball, H. (ed.). (1996). Psychological aspects of humanizing education: a book for a teacher. Kyiv-Rivne.

22. Rybalka, V. (1993). The method of determining the scientific and technical abilities in senior pupils. Psychology: Scientific and methodological collection. Kyiv: Osvita (Education), 40, 26-42.

23. Furman, A. Psychodiagnostics of the intelligence in the system of learning differentiation. Kyiv: Osvita (Education). 